\title{
KEY FACTS ON BAY AREA FOUNDATIONS
}

\section{Selected Grantmaker Data ${ }^{1}, 2009$}

Bay Area grantmakers represent a substantial segment of California's foundation community. In 2009, just over one-third of the state's grantmaking independent, corporate, community, and operating foundations were located in the nine-county Bay Area. These funders held close to half of California foundation assets (45 percent) and accounted for more than half of total giving (52.4 percent). Bay Area foundations reported the fastest growth in total giving and assets since 2000, compared to California and U.S. foundations overall.

${ }^{1}$ The Foundation Center's grantmaker database includes all non-terminated independent, corporate, community, and operating foundations. Sources of data for these foundations include IRS information returns (Form 990-PF), foundation reports, and information reported to the Foundation Center on annual surveys of foundations with assets of at least $\$ 100,000$ or giving of $\$ 50,000$ or more.

Summary Statistics for Bay Area Foundations, 2009

\begin{tabular}{lcrrrrr}
\hline County & $\begin{array}{c}\text { No. of } \\
\text { Foundations }\end{array}$ & \multicolumn{1}{c}{$\%$} & \multicolumn{1}{c}{ Assets } & \multicolumn{1}{c}{$\%$} & Total Giving & $\%$ \\
\hline Alameda & 235 & 9.4 & $\$ 1,675,015$ & 3.7 & $\$ 143,006$ & 4.6 \\
Contra Costa & 188 & 7.5 & $1,121,459$ & 2.5 & 70,147 & 2.2 \\
Marin & 190 & 7.6 & $2,757,006$ & 6.1 & 184,592 & 5.9 \\
Napa & 47 & 1.9 & 203,120 & 0.5 & 17,016 & 0.5 \\
San Francisco & 835 & 33.4 & $11,374,566$ & 25.3 & 912,666 & 29.1 \\
San Mateo & 298 & 11.9 & $10,625,443$ & 23.6 & 885,917 & 28.2 \\
Santa Clara & 608 & 24.3 & $16,802,444$ & 37.3 & 871,819 & 27.8 \\
Solano & 22 & 0.9 & 52,989 & 0.1 & 8,613 & 0.3 \\
Sonoma & 75 & 3.0 & 410,981 & 0.9 & 43,022 & 1.4 \\
TOTAL & $\mathbf{2 , 4 9 8}$ & $\mathbf{1 0 0 . 0}$ & $\mathbf{\$ 4 5 , 0 2 3 , 0 2 3}$ & 100.0 & $\$ 3,136,798$ & 100.0 \\
\hline
\end{tabular}

Note: Dollars in thousands. Due to rounding, figures may not add up. Figures exclude non-grantmaking foundations and grantmaking public charities.

\section{\$3.1 billion}

Giving by Bay Area

foundations in 2009

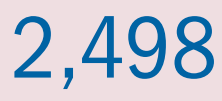

Number of grantmaking foundations in the Bay Area in 2009

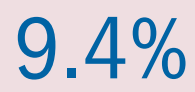

Share of Bay Area foundations reporting more than $\$ 1$ million in giving in 2009

\section{Education}

Top-ranked field by share of 2009 grant dollars for Bay Area Grantmakers-26.5\%
Close to three-fifths of Bay Area foundations held less than $\$ 1$ million in assets in 2009

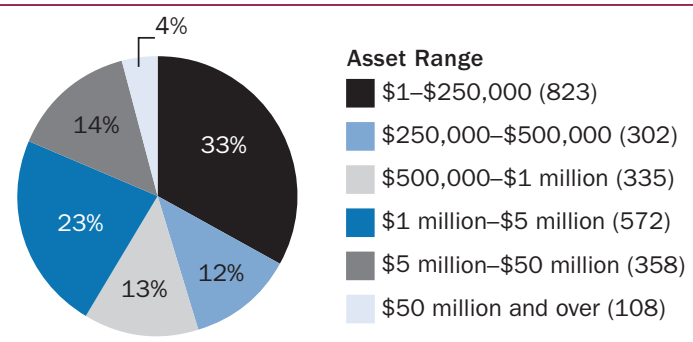

Percent of Number of Foundations

Note: Based on 2,498 grantmaking Bay Area foundations. Actual number per category shown in parentheses.
Half of Bay Area foundations gave less than $\$ 50,000$ in 2009

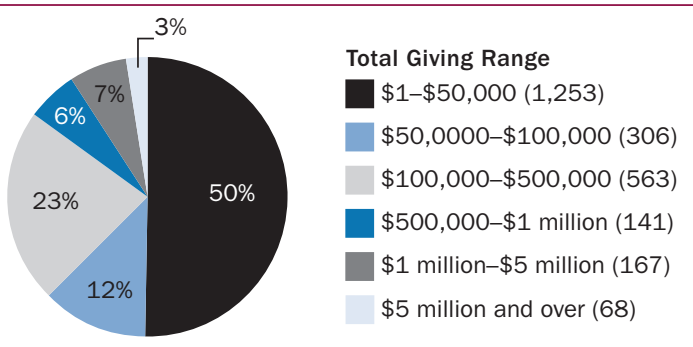

Percent of Number of Foundations

Note: Based on 2,498 grantmaking Bay Area foundations. Actual number per category shown in parentheses. 
Top Ten Bay Area Foundations by Assets, 2009

\begin{tabular}{lcrrr}
\hline \multicolumn{1}{c}{ Foundation Name } & $\begin{array}{c}\text { Foundation } \\
\text { Type }^{1}\end{array}$ & \multicolumn{1}{c}{ Assets } & $\begin{array}{c}\text { Fiscal } \\
\text { Date }\end{array}$ \\
\hline 1. William and Flora Hewlett Foundation & IN & $\$ 6,869,108,000$ & $12 / 31 / 09$ \\
2. David and Lucile Packard Foundation & IN & $5,699,231,606$ & $12 / 31 / 09$ \\
3. Gordon and Betty Moore Foundation & IN & $5,200,576,871$ & $12 / 31 / 09$ \\
4. Silicon Valley Community Foundation & CM & $1,749,109,000$ & $12 / 31 / 09$ \\
5. James Irvine Foundation & IN & $1,449,193,495$ & $12 / 31 / 09$ \\
6. Marin Community Foundation & CM & $1,014,427,025$ & $06 / 30 / 10$ \\
7. San Francisco Foundation & CM & $980,064,000$ & $06 / 30 / 10$ \\
8. Packard Humanities Institute & OP & $726,680,226$ & $12 / 31 / 09$ \\
9. Shimon ben Joseph Foundation & IN & $726,258,458$ & $12 / 31 / 09$ \\
10. Wayne \& Gladys Valley Foundation & IN & $510,651,317$ & $09 / 30 / 09$ \\
\hline
\end{tabular}

The Henry J. Kaiser Family Foundation was omitted from the list because updated fiscal information was not available. The foundation's 2008 assets were $\$ 534$ million. Does not include grantmaking public charities.

${ }^{1} \mathrm{IN}=$ Independent Foundation; $\mathrm{CM}=$ Community Foundation; $\mathrm{OP}=$ Operating Foundation
Top Ten Bay Area Foundations by Total Giving, 2009

\begin{tabular}{lcrcc}
\hline \multicolumn{1}{c}{ Foundation Name } & $\begin{array}{c}\text { Foundation } \\
\text { Type }^{1}\end{array}$ & \multicolumn{1}{c}{ Total Giving } & \multicolumn{1}{c}{$\begin{array}{c}\text { Fiscal } \\
\text { Date }\end{array}$} \\
\hline 1. William and Flora Hewlett Foundation & IN & $\$ 342,475,000$ & $12 / 31 / 09$ \\
2. Genentech Access To Care Foundation & OP & $292,060,925$ & $12 / 31 / 09$ \\
3. David and Lucile Packard Foundation & IN & $282,825,448$ & $12 / 31 / 09$ \\
4. Gordon and Betty Moore Foundation & IN & $169,993,004$ & $12 / 31 / 09$ \\
5. Silicon Valley Community Foundation & CM & $154,255,000$ & $12 / 31 / 09$ \\
6. San Francisco Foundation & CM & $75,639,000$ & $06 / 30 / 10$ \\
7. James Irvine Foundation & IN & $65,495,033$ & $12 / 31 / 09$ \\
8. Sea Change Foundation & IN & $56,130,802$ & $07 / 31 / 09$ \\
9. Marin Community Foundation & CM & $54,838,016$ & $06 / 30 / 10$ \\
10. East Bay Community Foundation & CM & $50,665,013$ & $06 / 30 / 09$
\end{tabular}

\section{Does not include grantmaking public charities.}

${ }^{1} \mathrm{IN}=$ Independent Foundation; $\mathrm{CM}=$ Community Foundation; $\mathrm{OP}=$ Operating Foundation.

${ }^{2}$ Includes grants, scholarships, and employee matching gifts; excludes set-asides, loans, PRIs, and program expenses.

\section{Change in Foundation Giving Since 2000}

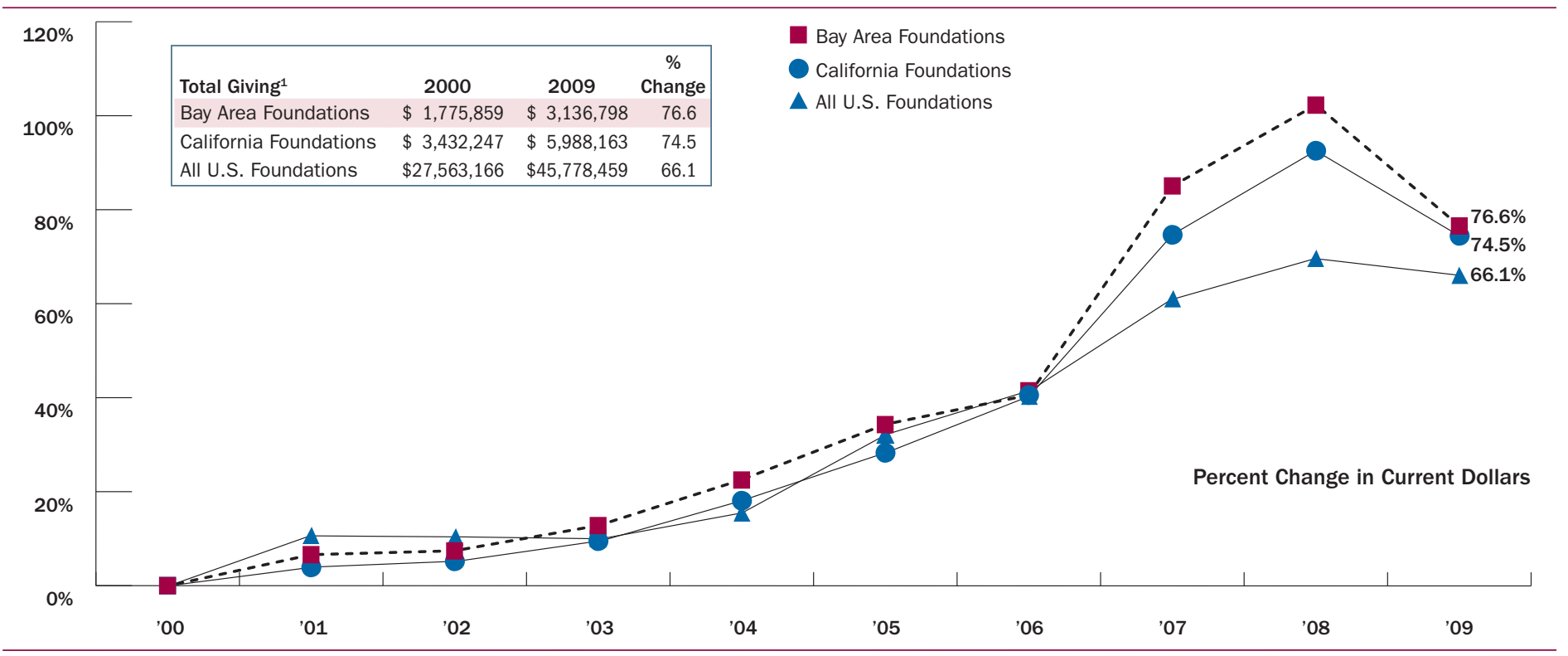

Source: The Foundation Center, 2011.

${ }^{1}$ Dollar Figures in thousands.

\section{Change in Foundation Assets Since 2000}

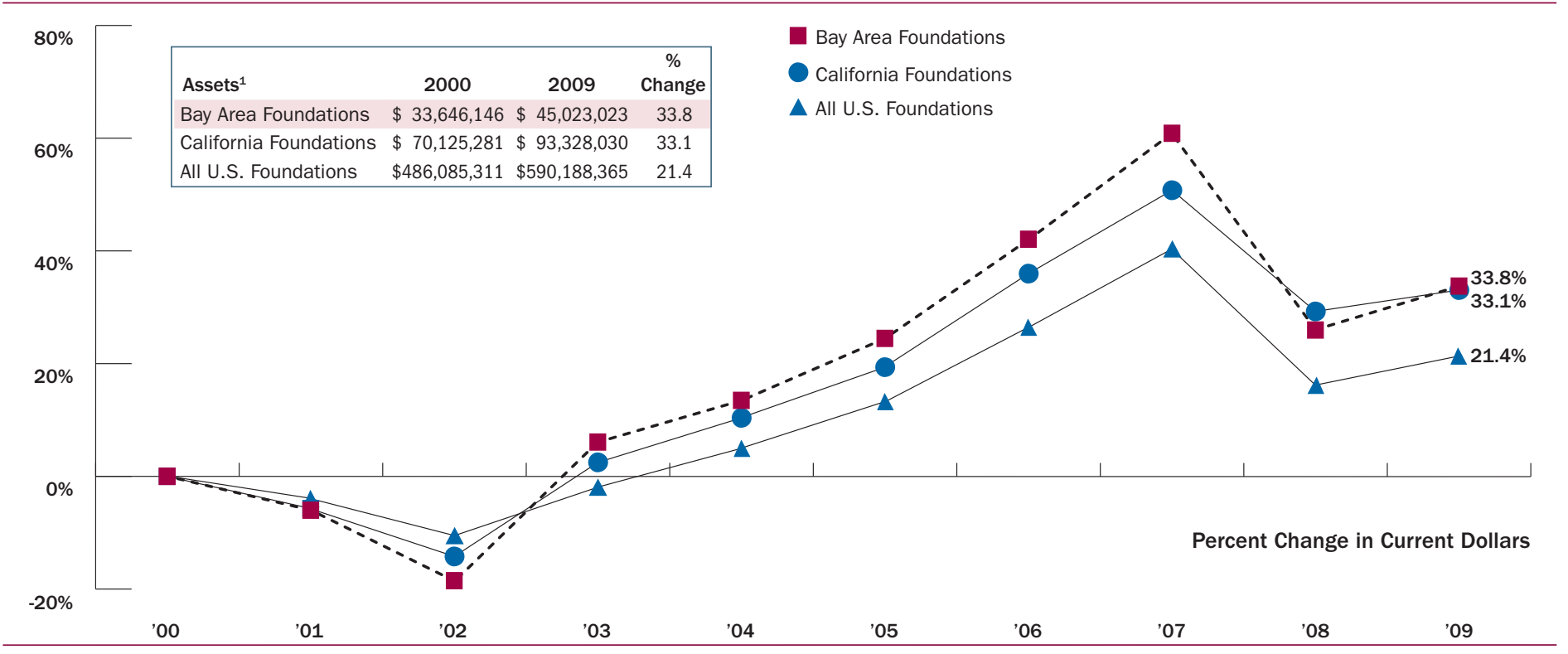

Source: The Foundation Center, 2011.

${ }^{1}$ Dollar Figures in thousands. 


\section{Selected Giving Patterns, 2009}

Bay Area foundations included in the Foundation Center's 2009 grants sample ${ }^{1}$ prioritized giving for education and the environment and animals, consistent with California foundations overall. Relative to the universe of California grantmakers in the sample, Bay Area funders provided a roughly similar share of their 2009 giving for education (26.5 percent vs. 24.1 percent) but notably larger shares for the environment ( 24 percent vs. 17.4 percent), science and technology ( 7.2 percent vs. 6 percent) and international affairs ( 5 percent vs. 3.8 percent). In contrast, they directed a substantially smaller share of their giving for health (8.6 percent vs. 15.8 percent) and human services (8.2 percent vs. 10.9 percent).

${ }^{1}$ The 2009 grants sample included all of the grants of $\$ 10,000$ or more awarded by 1,384 of the largest U.S. foundations and accounted for roughly half of grant dollars awarded by the nation's over 76,000 grantmaking foundations. Of the sampled foundations, 137 were based in California, including 74 Bay Area foundations. Giving by sampled Bay Area foundations represented roughly three-quarters of funding by all Bay Area foundations in 2009.

Bay Area foundations provided their largest shares of giving for program and operating support in 2009

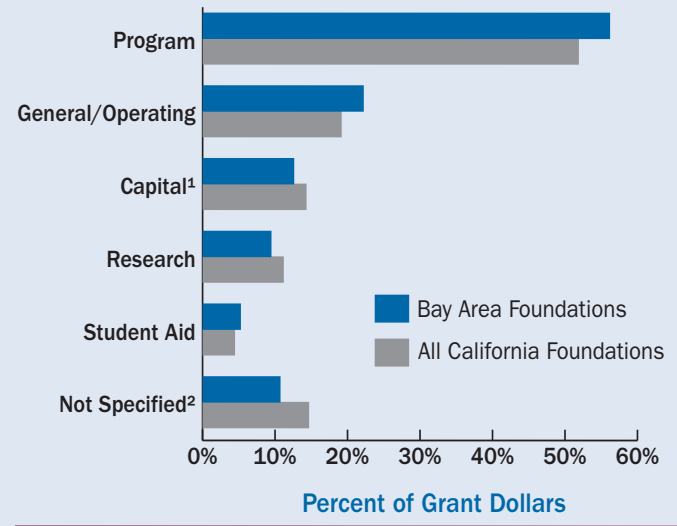

Note: Based on grants of $\$ 10,000$ or more awarded by a sample of 137 larger California foundations, including 74 Bay Area foundations.

${ }^{1}$ Capital support includes endowment funds.

${ }^{2}$ Approximately one-quarter of California foundation grants could not be coded for a type of support due to lack of sufficient descriptive information.

Top 10 Bay Area Foundations Awarding Grants to Bay Area Recipient Organizations, 2009

\begin{tabular}{lrr}
\hline Foundation Name & Dollar Amount & $\begin{array}{r}\text { No. } \\
\text { Grants }\end{array}$ \\
\hline 1. Silicon Valley Community Foundation & $\$ 109,719,808$ & 1,432 \\
2. David and Lucile Packard Foundation & $76,787,270$ & 237 \\
3. William and Flora Hewlett Foundation & $62,178,510$ & 216 \\
4. San Francisco Foundation & $54,959,855$ & 1,338 \\
5. Gordon and Betty Moore Foundation & $41,706,121$ & 103 \\
6. Marin Community Foundation & $40,994,818$ & 346 \\
7. James Irvine Foundation & $34,715,295$ & 97 \\
8. Wayne \& Gladys Valley Foundation & $26,367,075$ & 69 \\
9. Evelyn and Walter Haas, Jr. Fund & $25,324,500$ & 132 \\
10. East Bay Community Foundation & $24,408,817$ & 508 \\
\hline
\end{tabular}

Note: Based on grants of $\$ 10,000$ or more awarded by a sample of 74 larger Bay Area foundations.
Bay Area foundations favored education and the environment in 2009

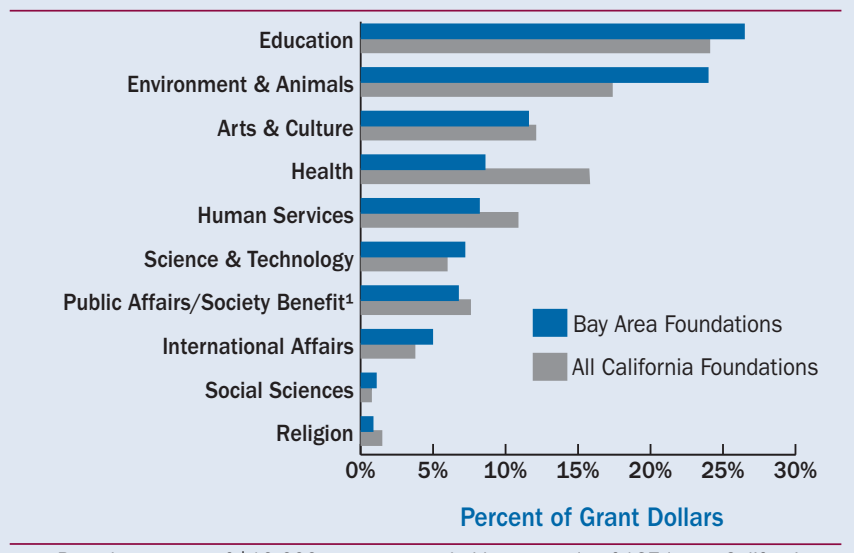

Note: Based on grants of $\$ 10,000$ or more awarded by a sample of 137 larger California foundations, including 74 Bay Area foundations.

IIncludes civil rights and social action, community improvement and development, philanthropy and voluntarism, and public affairs.

Bay Area foundations targeted their largest share of funding for the economically disadvantaged in 2009

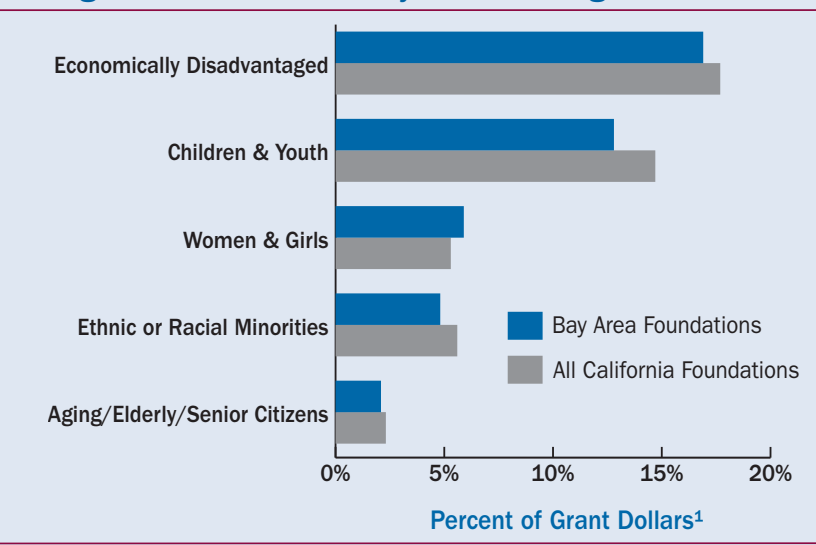

Note: Based on grants of $\$ 10,000$ or more awarded by a sample of 137 larger California foundations, including 74 Bay Area foundations.

${ }^{1}$ Figures represent only grants awarded to groups that could be identified as serving specific populations or grants whose descriptions specified a benefit for a specific population. These figures do not reflect all giving benefiting these groups. In addition, grants may benefit multiple population groups, e.g., a grant for homeless children, would therefore be counted more than once. For an analysis of giving by larger California foundations benefiting ethnic or racial minorities, see McGill, L. T., A. Austin, and B. Bryan. Embracing Diversity: Foundation Giving Benefiting California's Communities of Color. New York, NY: Foundation Center, 2008.

Top 10 Non-Bay Area Foundations Awarding Grants to Bay Area Recipient Organizations, 2009

\begin{tabular}{lcrr}
\hline \multicolumn{1}{c}{ Foundation Name } & State & Dollar Amount & $\begin{array}{c}\text { No. } \\
\text { Grants }\end{array}$ \\
\hline 1. Bill \& Melinda Gates Foundation & WA & $\$ 86,729,688$ & 51 \\
2. Susan Thompson Buffett Foundation & NE & $42,402,920$ & 24 \\
3. The California Endowment & CA & $32,854,559$ & 203 \\
4. Ford Foundation & NY & $24,858,315$ & 86 \\
5. Knight Foundation & OR & $20,000,000$ & 1 \\
6. Robert Wood Johnson Foundation & NJ & $17,682,434$ & 45 \\
7. Open Society Institute & NY & $16,293,988$ & 84 \\
8. The California Wellness Foundation & CA & $12,690,000$ & 67 \\
9. Hansjoerg Wyss Foundation & PA & $12,500,000$ & 1 \\
10. W.K. Kellogg Foundation & MI & $12,149,472$ & 32 \\
\hline
\end{tabular}

Note: Based on grants of $\$ 10,000$ or more awarded by a sample of 1,384 larger foundations. Grantmaker location is based on the address listed on the organization's tax return. 